\title{
Concrete Mix Design By Packing Density Method
}

\author{
Narasimha Raj ${ }^{1}$, Suresh G Patil ${ }^{2}$ and B. Bhattacharjee ${ }^{3}$ \\ ${ }^{1,2}$ Department of civil engineering, PDA College of engineering, Gulbarga \\ ${ }^{3}$ Department of civil engineering, Indian Institute of Technology, Delhi.
}

\begin{abstract}
Packing density is new kind of mix design method used to design different types of concrete. To optimize the particle packing density of concrete, the particles should be selected to fill up the voids between large particles with smaller particles and so on, in order to obtain a dense and stiff particle structure. Higher degree of particle packing leads to minimum voids, maximum density and requirement of cement and water will be less. In this work the co-relation curves are developed for packing density method between compression strength and water cement ratio, paste content to reduce the time involved in trial to decide water cement ratio and paste content for a particular grade of concrete. Results obtained by packing density method are compared with IS code method. The optimum bulk density was obtained at proportion of $42 \%$ coarse aggregates $(20 \mathrm{~mm}$ downsize), $18 \%$ coarse aggregates (12.5mm downsize) and $40 \%$ fine aggregates. Large number of trial casting were carried out for each grade of concrete (i.e., M20, M25, M30, M35 and M40) with different water cement ratio and three paste contents in excess of void content. To finalise mix proportions using packing density method flow table tests were carried out to decide water cement ratio and paste content in excess of void content for each grade of concrete. The finalised mix proportion for each grade of concrete was used to cast the cube specimens for 7 days and 28 days curing age. The cube compressive strength results obtained by packing density and IS code method are nearly same. The co-relation curves were plotted for packing density results alone and also combining the results of packing density and IS code methods. The co-relation curves were plotted between compressive strength vs water cement ratio at 7 and 28 days curing age and compressive strength vs paste content at 7 and 28 days curing age. Very good co-relation is obtained with a co-relation coefficient of 0.953 (minimum) to 0.998 (maximum). These curves can be used to decide the water cement ratio and paste content for the specified grade of concrete incase of packing density method thus reducing the material and time involved in trial testing.
\end{abstract}

Keywords: Bulk density, voids ratio, packing density, mix design, plotting.

\section{Introduction}

There are various methods of proportioning for various types of concrete. Packing density method of mix design is the only mix design method used for proportioning normal concrete, high strength concrete, nofines concrete and self compacting concrete. No adequate literature is available on this method.

The subject of optimizing the concrete composition by selecting the right amounts of various particles has already aroused interest for more than a century. To optimize the particle packing density of concrete, the particles should be selected to fill up the voids between large particles with smaller particles and so on, in order to obtain a dense and stiff particle structure. Most of the early researchers, working on the packing of aggregates, proposed methods to design an ideal particle size distribution. Geometrically based particle packing models can help to predict the water demand of concrete, and thus the material properties.

The cement paste has to fill up the voids between aggregate particles and the "excess" paste will then disperse the aggregate particles to produce a thin coating of paste surrounding each aggregate for lubricating the concrete mix. In general, the higher the packing density of the aggregate, the smaller will be the volume of voids to be filled and larger will be the amount of paste in excess of void for lubrication.

In IS code method of mix design we have curves to decide the water cement ratio whereas in packing density method we don't have such type of co-relation curves available. Here an attempt has made to develop co-relation curves between compressive strength of concrete versus water cement ratio and paste content versus Compressive strength. These co-relation curves help to reduce the trials and decide the water cement ratio and paste content for the given grade of concrete.

Wong and Kwan [1] used the ordinary Portland cement complying with BS 12:1996. Fennis and Walraven [3] used ordinary Portland cement and blast furnace slag cement. Wong and Kwan [2] used the aggregate particles smaller than $1.2 \mathrm{~mm}$ for mortar and aggregate particles larger than $1.2 \mathrm{~mm}$ for concrete mix. Kwan and Wong [2] used pulverised flyash as cementitious material complying with BS 3892: Part 1: 1982. Kwan and Wong[2] used the condensed silica fume complying with ASTM C 1240-03 as the cementitious material in their experiments. Kwan and Wong [2] in their studies used two types of superplasticisers a polycarboxylate based and cross linked polymer and naphthalene based formaldehyde condensate. 
Kwan and Wong [2] measured the packing densities of cementitious materials containing ordinary Portland cement, pulverised fly ash and condensed silica fume. The results for non-blended materials revealed that the addition of a superplasticiser would always increase the packing densities of ordinary Portland cement and pulverised flyash, the addition of a polycarboxylate based superplasticiser could decrease the packing density of condensed silica fume.

Fennis and Walraven [3] studied on measuring the packing density to lower the cement content in concrete. It is described how centrifugal consolidation can be used to determine the packing density of powders. The method is assessed based on experimental data, calculations and polarization and fluorescence microscopy of the samples.

Kwan and Wong [1]proposed three tier system design. The mix design would be divided into three stages. At first stage the packing density of the cementitiious materials would determine the water demand, and at the second stage the aggregate particles smaller then $1.2 \mathrm{~mm}$ would determine the paste demand and at third stage the aggregate particles larger then $1.2 \mathrm{~mm}$ would determine the mortar demand.

Glavind and Pederson [5] studied that when selecting a concrete mix design, it is always desirable to compose the aggregates as densely as possible, i.e. with maximum packing. That minimises the necessary amount of binder which has to fill the cavities between the aggregates for a constant concrete workability. Apart from an obvious economic benefit, a minimum of binder in concrete results in less shrinkage and creep and a more dense and therefore probably a more durable and strong concrete type.

V.L. Kantha rao \& S. Krishnamoorthy, [6] have studied the proportions required for least void content followed a linear trend fairly similar to what one would obtained from the theoretical gradings of fuller. An empirical equation has been fitted for this linear trend so that it can be used to determine the proportions of coarse and fine aggregate of least void contents.

Powers [7], in his studies on aggregate mixtures showed that the voids ratio of a binary particulate system would be minimum at a particular combination. Voids ratio $(\mathrm{U})$ is defined as the ratio between the volume of voids (E) and the volume of solids (I-E) of a particulate system.

Kwan and Wong used the mini-slump cone test to check the fresh state properties in their experimental studies. Fennis and Walraven [2] carried out the centrifugal consolidation to check the workability. Kwan and Wong [4] obtained curve between voids ratio and water cement ratio for cementatious materials, where the ordinary Portland cement is blended with the pulverised fuel ash and condensed silica fume in different proportions.

From the above study it is observed that packing density mix design method is used to minimize voids to increase particle packing and to reduce the binder content. Very less information is available regarding corelation between grade of concrete and water cementatious ratio, paste content, incase of packing density.

\section{Materials}

Ordinary Portland cement confirming to IS 12269-1987 [8] locally available river sand belonging to zone II of IS 383-1970 [9], was used. Locally available crushed aggregate of size $12.5 \mathrm{~mm}$ and $20 \mathrm{~mm}$ down size conforming to IS 383-1970 [9] were used in the preparation of concrete. Potable water was used in the present investigation for both casting and curing of the concrete. Superplasticizer complies with IS 9103:1999 [10] Sulphonated Napthelene based polymers is used. Bulk density and specific gravity test were carried out as per IS 2386(Part III)-1963 [11] and the test results are presented in Table 1.

Table 1: Bulk density and Specific gravity

\begin{tabular}{|l|l|l|l|l|}
\hline $\begin{array}{l}\text { Sl. } \\
\text { No. }\end{array}$ & Materials & $\begin{array}{l}\text { Bulk density } \mathrm{Kg} / \mathrm{m}^{3} \\
\text { (Compacted condition) }\end{array}$ & $\begin{array}{l}\text { Bulk density } \mathrm{Kg} / \mathrm{m}^{3} \\
\text { (Loose condition) }\end{array}$ & $\begin{array}{l}\text { Specific } \\
\text { gravity }\end{array}$ \\
\hline 1 & Fine aggregates & 1600.133 & 1718.063 & 2.593 \\
\hline 2 & Coarse aggregate $12.5 \mathrm{~mm}$ & 1387.777 & 1542.222 & 2.937 \\
\hline 3 & Coarse aggregate $20 \mathrm{~mm}$ & 1525.555 & 1660.000 & 2.912 \\
\hline
\end{tabular}

\section{Design of Concrete Mix Using Packing Density Method}

\section{Determination of aggregate fractions}

The packing density of aggregate mixture is defined as the solid volume in a unit total volume. The aim of obtaining packing density is to combine aggregate particles in order to minimize the porosity, which allows the use of least possible amount of binder.

Two size fractions of coarse aggregates were selected for the study i.e., $20 \mathrm{~mm}$ and $12.5 \mathrm{~mm}$ down size. The values of bulk density of the coarse aggregates $(20 \mathrm{~mm}$ and $12.5 \mathrm{~mm}$ size) were first determined separately. The coarse aggregate $20 \mathrm{~mm}$ and $12.5 \mathrm{~mm}$ were mixed in different proportions by mass, such as 90:10, 80:20, 70:30 and 60:40 etc., and the bulk density of each mixture is determined. Addition of smaller size aggregate $(12.5 \mathrm{~mm}$ down size) increases the bulk density. However a stage is reached when the bulk density of coarse 
aggregate mixture, which instead of increasing, decreases again. The results of Bulk density of coarse aggregate fractions $(20 \mathrm{~mm}$ and $12.5 \mathrm{~mm})$ are plotted in Fig. 1 .

\section{Determination of Packing Density}

The packing density of individual aggregate in a volume fraction of total aggregate or over all aggregate is determined from its maximum bulk density of mixture and specific gravity from the following relation.

$$
\text { Packing density }=\frac{\text { Bulk density } \mathrm{x} \text { weight fraction }}{\text { Specific gravity }}
$$

Therefore total packing density of the mixture is sum of packing density of $20 \mathrm{~mm}, 12.5 \mathrm{~mm}$ and fine aggregate i.e., equal to the ratio of bulk density of mixture to specific gravity of individual aggregate ( $20 \mathrm{~mm}$ : $12.5 \mathrm{~mm}$ : fine aggregate). The value of specific gravity should be taken as average, if the values are differing in third decimal and if the values are differing in second decimal, the individual values should be taken for calculating packing density and voids content.

\section{Determination of Voids Contents and Voids ratio}

The voids content in percentage volume of aggregate or mixture of three aggregate is determined from its bulk density from the following relations.

Voids content in percent volume $=\frac{\text { Specific gravity }- \text { Bullk density }}{\text { Specific gravity }} \times 100$

From the Figures 1, 2 and 3 it is observed that the bulk density, packing density are maximum and voids ratio is minimum for $70 \%$ of coarse aggregate $(20 \mathrm{~mm})$ and $30 \%$ of coarse aggregate $(12.5 \mathrm{~mm})$ respectively.

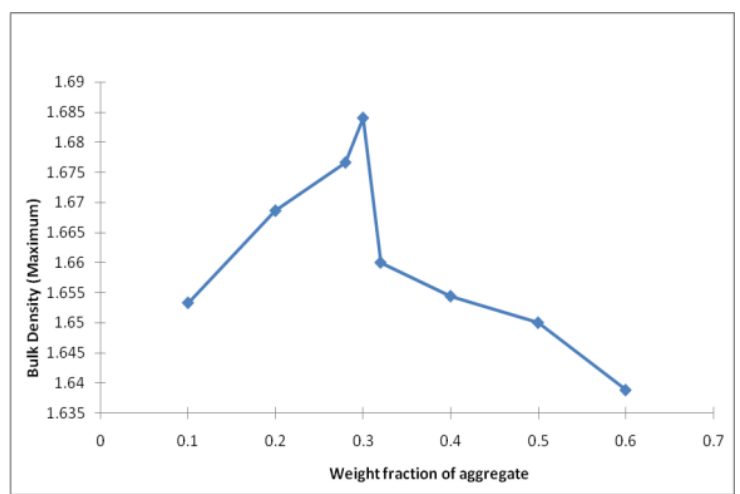

Fig 1: Maximum bulk density for $20 \mathrm{~mm}$ and $12.5 \mathrm{~mm}$ aggregates

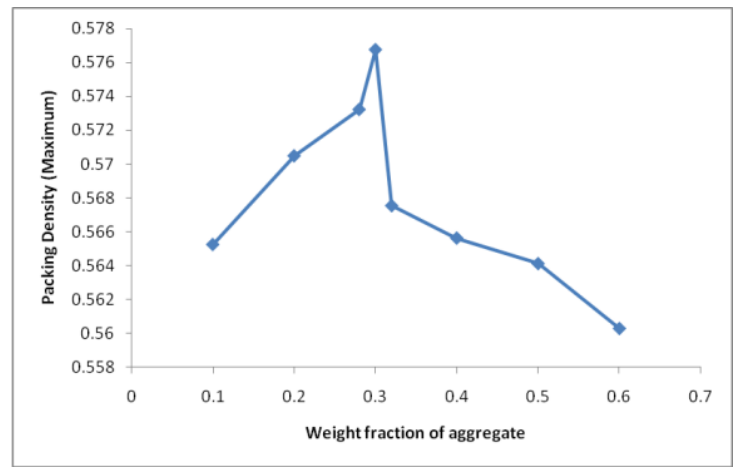

Fig 2: Maximum packing density for $20 \mathrm{~mm}$ and $12.5 \mathrm{~mm}$ aggregates 


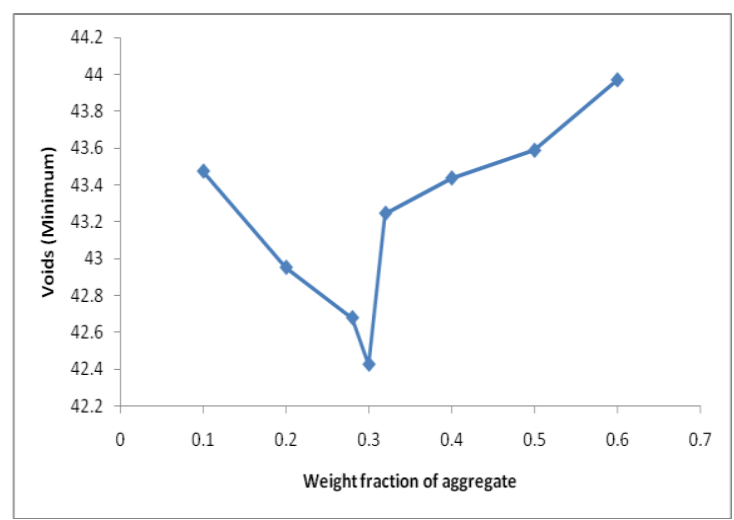

Fig 3: Minimum voids ratio for $20 \mathrm{~mm}$ and $12.5 \mathrm{~mm}$ aggregates

Increase in fine aggregate particles leads to decrease in void content thus increases the bulk density. The replacement of fine aggregates in the total coarse aggregates $(20 \mathrm{~mm}$ and $12.5 \mathrm{~mm}$ down size in the proportion 70:30) in the ratio of $90: 10,80: 20,70: 30,60: 40,55: 45$. By increasing the finer content the bulk density increases up to a maximum extent after which it again reduces. Thus the proportion obtained for maximum bulk density is fixed as total coarse aggregates : fine aggregates i.e., $60: 40$. Total coarse aggregate proportion i.e., $20 \mathrm{~mm}: 12.5 \mathrm{~mm}$ is fixed as $70: 30$ as mentioned earlier. Therefore proportions of these aggregates i.e., coarse aggregates $20 \mathrm{~mm}$ : coarse aggregates $12.5 \mathrm{~mm}$ : fine aggregates is $42: 18: 40$. The bulk density, packing density and voids ratio are plotted against the mass fraction of coarse aggregate are presented in the Figures 4, 5 and 6 respectively. From the Fig. 4, 5 and 6 maximum bulk density 2.007 gm/cc, maximum packing density $0.722 \mathrm{gm} / \mathrm{cc}$ and minimum voids content is 0.2866 .

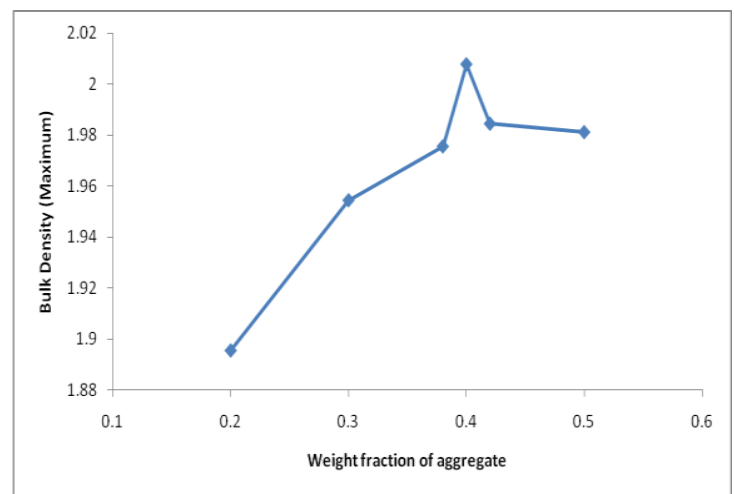

Fig 4: Maximum bulk density for $20 \mathrm{~mm}, 12.5 \mathrm{~mm}$ and fine aggregate

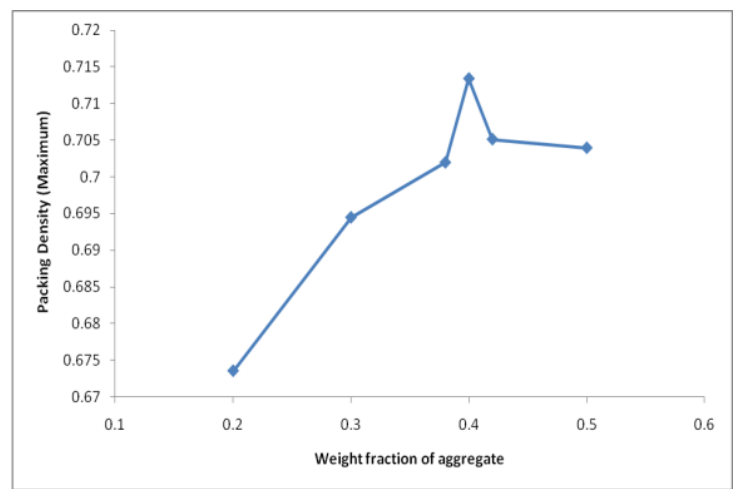

Fig 5: Maximum packing density for $20 \mathrm{~mm}, 12.5 \mathrm{~mm}$ and fine aggregate 


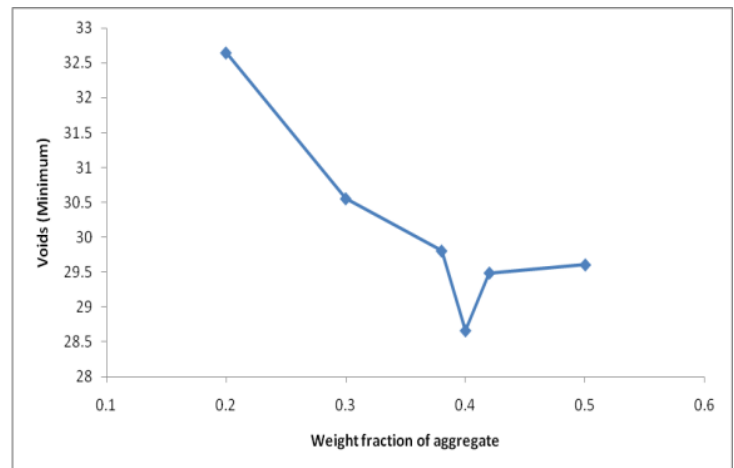

Fig 6: Minimum voids for $20 \mathrm{~mm}, 12.5 \mathrm{~mm}$ and fine aggregate

Using the above concept, design of concrete mix is carried out for M20, M25, M30, M35 and M40 concrete mixes. A detailed sample calculation for M20 grade of concrete is presented below. The ingredients of concrete for M20 grade were obtained for 5\%, 10\% and 15\% in excess of paste content and water cement ratio 0.56 and 0.58 the values are presented in Table 2 .

\section{Mix Design for M20 Grade Concrete (Packing Density Method)} density.

The calculations are presented in the following paragraph for bulk density, voids ratio and packing

(1) Bulk density of combined coarse aggregate $20 \mathrm{~mm}$ and $12.5 \mathrm{~mm}$ in the proportion $70: 30$.

$$
\text { Bulk Density }=\frac{W_{2}-W_{1}}{\text { Volume of mould }}
$$

Where, $\mathrm{W} 1$ = empty weight of mould

$\mathrm{W} 2=$ weight of mould + aggregate filled

Bulk density $($ maximum $)=\frac{35066-9800}{15000}$

$$
=1.6840 \mathrm{gm} / \mathrm{cm}^{3}
$$

(2) Bulk density of three aggregates i.e., CA $20 \mathrm{~mm}:$ CA $12.5 \mathrm{~mm}:$ FA is $42: 18: 40$. (coarse aggregate 20 $\mathrm{mm}: 12.5 \mathrm{~mm}$ i.e., $70: 30$ as fixed earlier).

Bulk density $($ Maximum $)=\frac{39916-9800}{15000}$

(3) Voids content:

$$
=2.0077 \mathrm{gm} / \mathrm{cm}^{3}
$$

Voids content in percent volume $=\frac{2.8143-2.0077}{2.8143} \times 100$

(4) Packing density (P.D.):

$$
=28.660 \%
$$

Packing density $($ maximum $)=\frac{\text { Bulk density } x \text { weight fraction }}{\text { Specific gravity }}$

Packing density of 20mm aggregates $=\frac{2.00778 \times 0.420}{2.9122}$

$$
=0.2896 \mathrm{gm} / \mathrm{cm}^{3}
$$


Packing density of $12.5 \mathrm{~mm}$ aggregates $=\frac{2.0078 \times 0.180}{2.9376}$

$$
=0.1230 \mathrm{gm} / \mathrm{cm}^{3}
$$

$$
\begin{aligned}
\text { Packing density of fine aggregates }= & \frac{2.00778 \times 0.400}{2.5931} \\
& =0.3097 \mathrm{gm} / \mathrm{cm}^{3}
\end{aligned}
$$

Total Packing Density = Packing Density of CA $(20 \mathrm{~mm})+$ Packing Density of CA $(12.5 \mathrm{~mm})+$ Packing Density of Fine Aggregate

$\mathrm{PD}=0.7223 \mathrm{gm} / \mathrm{cm}^{3}$

This packing density value is fixed for further calculations.

\section{Determination of Paste content for M20 Grade Concrete}

Minimum paste content is sum of the void content in combined aggregate and excess paste over and above it to coat the aggregate particle. Meaning of minimum paste content can be explained as, a concrete mix containing minimum paste content should be cohesive, free from segregation and bleeding. Flow table test were carried out to decide the minimum paste contents required to form the workable mix for different $\mathrm{W} / \mathrm{C}$ ratio and different paste content in excess of void content.

Voids content $=1-0.7223=0.2777$

Assuming paste content as $10 \%$ in excess of void content, detailed calculations to obtain all the ingredients of concrete such as coarse aggregate $20 \mathrm{~mm}, 12.5 \mathrm{~mm}$, fine aggregate, cement and water content is given below.

Paste content $10 \%$ in excess of void content

Paste content $=0.2777+0.1 \times 0.2777$

$$
=0.3054
$$

Volume of aggregates $=1-0.3054$

$$
=0.6945 \mathrm{cc}
$$

Total solid volume of aggregates $=\frac{\text { Weight fraction of } 20 \mathrm{~mm}}{\text { Specific gravity }}+\frac{\text { Weight fraction of } 12.5 \mathrm{~mm}}{\text { Specific gravity }}$

$$
+\frac{\text { Weight fraction of fine aggregate }}{\text { Specific gravity }}
$$

Total Solid volume of aggregates $=\frac{0.420}{2.9122}+\frac{0.180}{2.9376}+\frac{0.400}{2.5931}$

$$
=0.3598 \mathrm{cc}
$$

Weight of 20mm aggregates $=\frac{0.6945}{0.3598} \times 0.420 \times 1000=810.7354 \mathrm{Kg} / \mathrm{Cum}$

Weight of $12.5 \mathrm{~mm}$ aggregates $=\frac{0.6945}{0.3598} \times 0.180 \times 1000=347.4580 \mathrm{Kg} / \mathrm{Cum}$

Weight of fine aggregates $=\frac{0.6945}{0.3598} \times 0.400 \times 1000=722.1290 \mathrm{Kg} / \mathrm{Cum}$

For M20 grade concrete keeping in mind the target mean strength suitable water-cement ratio is fixed as per trial mixes.

$$
\begin{aligned}
\mathrm{W} / \mathrm{C} \text { ratio }=0.56 ; \mathrm{W} & =0.56 \mathrm{C} \\
\text { Total Paste } & =\mathrm{C}+\mathrm{W}=\frac{C}{3.15}+\frac{0.56 C}{1}=0.8775 \mathrm{C}
\end{aligned}
$$




$$
\text { Cement content }=\frac{0.3054}{0.8775} \times 1000=348.1140 \mathrm{Kg} / \mathrm{Cum}
$$

Water content $=0.56 \times 348.1140$

$$
=194.9438 \mathrm{Kg} / \mathrm{cum}
$$

Following the above procedure all the ingredients of concrete were obtained for $5 \%, 10 \%$ and $15 \%$ in excess of paste content and water cement ratio 0.56 and 0.58 , the values are presented in Table 2.

\begin{tabular}{|c|c|c|c|c|c|c|c|}
\hline $\begin{array}{l}\text { Grade of } \\
\text { concrete }\end{array}$ & $\begin{array}{l}\mathrm{W} / \mathrm{C} \\
\text { ratio }\end{array}$ & $\begin{array}{l}\text { Excess } \\
\text { paste } \\
\text { content }(\%)\end{array}$ & $\begin{array}{l}\text { Water } \\
\text { content } \\
\left(\mathrm{Kg} / \mathrm{m}^{3}\right)\end{array}$ & $\begin{array}{l}\text { Cement } \\
\text { content } \\
\left(\mathrm{Kg} / \mathrm{m}^{3}\right)\end{array}$ & $\begin{array}{l}\text { Wt. Of Fine } \\
\text { aggregate } \\
\left(\mathrm{Kg} / \mathrm{m}^{3}\right)\end{array}$ & $\begin{array}{l}\text { Wt. Of } 12 \mathrm{~mm} \\
\text { Coarse } \\
\text { aggregate } \\
\left(\mathrm{Kg} / \mathrm{m}^{3}\right)\end{array}$ & $\begin{array}{l}\text { Wt. Of } 20 \mathrm{~mm} \\
\text { Coarse } \\
\text { aggregate } \\
\left(\mathrm{Kg} / \mathrm{m}^{3}\right)\end{array}$ \\
\hline \multirow{12}{*}{ M20 } & \multirow{2}{*}{0.58} & \multirow{2}{*}{5} & 188.4416 & 324.8994 & 787.6736 & 354.4531 & 827.0573 \\
\hline & & & 0.58 & 1 & 2.4243 & 1.0817 & 2.5455 \\
\hline & \multirow{2}{*}{0.58} & \multirow{2}{*}{10} & 197.4151 & 340.3708 & 772.2352 & 347.5058 & 810.8469 \\
\hline & & & 0.58 & 1 & 2.2688 & 1.0209 & 2.3822 \\
\hline & \multirow{2}{*}{0.58} & \multirow{2}{*}{15} & 206.3885 & 355.8422 & 756.7967 & 340.5585 & 794.6366 \\
\hline & & & 0.58 & 1 & 2.1268 & 0.9570 & 2.2331 \\
\hline & \multirow{2}{*}{0.56} & \multirow{2}{*}{5} & 186.0907 & 332.3048 & 787.6736 & 354.4531 & 827.0573 \\
\hline & & & 0.56 & 1 & 2.3703 & 1.0667 & 2.4889 \\
\hline & \multirow{2}{*}{0.56} & \multirow{2}{*}{10} & 194.9522 & 348.1289 & 772.2352 & 347.5058 & 810.8469 \\
\hline & & & 0.56 & 1 & 2.2182 & 0.9982 & 2.3292 \\
\hline & \multirow{2}{*}{0.56} & \multirow{2}{*}{15} & 203.8136 & 363.9529 & 756.7967 & 340.5585 & 794.6366 \\
\hline & & & 0.56 & 1 & 2.0794 & 0.9357 & 2.1834 \\
\hline
\end{tabular}

Table 2: Trial mix proportions for M20 grade concrete

To decide the paste content and water cement ratio among three paste content and two water cement ratios, using the above ingredients Flow Table tests were carried out. Flow Table test is carried out as per IS 1199-1959 [12]. Results of Flow table tests for M20 grade concrete indicated that water cement ratio 0.58 and all the three paste content (i.e., 5\%, 10\% and $15 \%$ ) and water cement ratio 0.56 with 5\% paste content were rejected because of segregation and bleeding. Water cement ratio 0.56 with paste content of $10 \%$ and $15 \%$ in excess of void content resulted in good flow percent of 133 and 134 respectively without segregation and bleeding. For water cement ratio 0.56 in order to decide the paste content i.e., $10 \%$ and $15 \%$ in excess of void content, trial cube casting was carried out for 7 days cube compressive strength. The average compressive strength ( 3 cubes) obtained at the end of 7 days curing was $22.88 \mathrm{~N} / \mathrm{mm}^{2}$ and $23.666 \mathrm{~N} / \mathrm{mm}^{2}$ for $10 \%$ and $15 \%$ paste content respectively. Keeping economy in mind paste content of $10 \%$ for water cement ratio 0.56 was finalised for further casting.

Mix design is carried for M25, M30, M35 and M40 grade concrete as mentioned in mix design steps for M20 grade concrete. The value of packing density remains same irrespective of grade of concrete because coarse aggregate $20 \mathrm{~mm}, 12.5 \mathrm{~mm}$ and fine aggregate used is same for all grades of concrete.

Depending on grade of concrete paste content will vary, increases with increase in grade of concrete. Water cement ratio for different grades of concrete (M25, M30, M35 and M40) is fixed as per trial mixes. Paste contents for different grades of concrete were determined using flow table tests as mentioned earlier.

For individual grade of concrete finalised mix proportions are presented in Table 3. 
Table 3: Finalised mix proportions designed by packing density method

\begin{tabular}{|c|c|c|c|c|c|c|c|}
\hline $\begin{array}{l}\text { Grade of } \\
\text { concrete }\end{array}$ & $\begin{array}{l}\mathrm{W} / \mathrm{C} \\
\text { ratio }\end{array}$ & $\begin{array}{l}\text { Excess } \\
\text { paste } \\
\text { content } \\
(\%)\end{array}$ & $\begin{array}{l}\text { Water } \\
\text { content } \\
\left(\mathrm{Kg} / \mathrm{m}^{3}\right)\end{array}$ & $\begin{array}{l}\text { Cement } \\
\text { content } \\
\left(\mathrm{Kg} / \mathrm{m}^{3}\right)\end{array}$ & $\begin{array}{l}\text { Wt. Of Fine } \\
\text { aggregate } \\
\left(\mathrm{Kg} / \mathrm{m}^{3}\right)\end{array}$ & $\begin{array}{l}\text { Wt. Of } 12 \mathrm{~mm} \\
\text { Coarse } \\
\text { aggregate } \\
\left(\mathrm{Kg} / \mathrm{m}^{3}\right)\end{array}$ & $\begin{array}{l}\text { Wt. Of } 20 \mathrm{~mm} \\
\text { Coarse } \\
\text { aggregate } \\
\left(\mathrm{Kg} / \mathrm{m}^{3}\right)\end{array}$ \\
\hline \multirow{2}{*}{ M20 } & \multirow{2}{*}{0.56} & \multirow{2}{*}{10} & 194.9522 & 348.1289 & 772.2352 & 347.5058 & 810.8469 \\
\hline & & & 0.56 & 1 & 2.2182 & 0.9982 & 2.3292 \\
\hline \multirow{2}{*}{ M25 } & \multirow{2}{*}{0.54} & \multirow{2}{*}{15} & 201.1187 & 372.4420 & 756.7967 & 340.5585 & 794.6366 \\
\hline & & & 0.54 & 1 & 2.0320 & 0.9144 & 2.1336 \\
\hline \multirow{2}{*}{ M30 } & \multirow{2}{*}{0.50} & \multirow{2}{*}{20} & 203.8259 & 407.6518 & 741.3583 & 333.6112 & 778.4262 \\
\hline & & & 0.50 & 1 & 1.8186 & 0.8184 & 1.9095 \\
\hline \multirow{2}{*}{ M35 } & \multirow{2}{*}{0.48} & \multirow{2}{*}{25} & 208.9378 & 435.2871 & 725.9199 & 326.6639 & 762.2159 \\
\hline & & & 0.48 & 1 & 1.6677 & 0.7505 & 1.7511 \\
\hline \multirow{2}{*}{ M40 } & \multirow{2}{*}{0.44} & \multirow{2}{*}{30} & 209.7061 & 476.6047 & 710.4815 & 319.7167 & 746.0055 \\
\hline & & & 0.44 & 1 & 1.4907 & 0.6708 & 1.5653 \\
\hline
\end{tabular}

\section{Design of Concrete Mix Using IS Code Method}

Mix design is also carried out using IS code 10262-2009 [13]. The objective of IS code method of mix design is to compare the ingredients of concrete (mix proportions) with the packing density method and also to compare the compressive strength at 28 days in these two cases and relevant observations were discussed.

Here also the final mix proportions were obtained for M20, M25, M30, M35 and M40 grade of concrete using IS method with different trial mix. The trial mix design for different grades of concrete was carried for different water cement ratios and workability is checked using Flow Table tests. Accepted trial mixes was further used to cast the trial cube specimens and were tested for compressive strength at the 7 days curing age. Observing the results of trial casting the appropriate mix is finalised. This finalised mix proportion is used for further casting.

Finalised mix proportions for different grades of concrete designed by IS code method is presented in Table 4 .

Table 4: Finalised mix proportions designed by IS code method

\begin{tabular}{|c|c|c|c|c|c|c|}
\hline $\begin{array}{l}\text { Grade of } \\
\text { concrete }\end{array}$ & $\mathrm{W} / \mathrm{C}$ ratio & $\begin{array}{l}\text { Water content } \\
\left(\mathrm{Kg} / \mathrm{m}^{3}\right)\end{array}$ & $\begin{array}{l}\text { Cement } \\
\text { content } \\
\left(\mathrm{Kg} / \mathrm{m}^{3}\right)\end{array}$ & $\begin{array}{l}\text { Wt. Of Fine } \\
\text { aggregate } \\
\left(\mathrm{Kg} / \mathrm{m}^{3}\right)\end{array}$ & $\begin{array}{l}\text { Wt. Of } 12 \mathrm{~mm} \\
\text { Coarse } \\
\text { aggregate } \\
\left(\mathrm{Kg} / \mathrm{m}^{3}\right)\end{array}$ & $\begin{array}{l}\text { Wt. Of } 20 \mathrm{~mm} \\
\text { Coarse } \\
\text { aggregate } \\
\left(\mathrm{Kg} / \mathrm{m}^{3}\right)\end{array}$ \\
\hline \multirow{2}{*}{ M20 } & \multirow{2}{*}{0.55} & 192 & 349 & 669 & 609.7 & 609.7 \\
\hline & & 0.55 & 1 & 1.9169 & 1.7470 & 1.7470 \\
\hline \multirow{2}{*}{ M25 } & \multirow{2}{*}{0.52} & 192 & 369.23 & 662.786 & 633.70 & 633.70 \\
\hline & & 0.52 & 1 & 1.7950 & 1.7162 & 1.7162 \\
\hline \multirow{2}{*}{ M30 } & \multirow{2}{*}{0.48} & 197 & 410 & 646 & 617 & 617 \\
\hline & & 0.48 & 1 & 1.5756 & 1.5048 & 1.5048 \\
\hline \multirow{2}{*}{ M35 } & \multirow{2}{*}{0.46} & 197 & 428 & 638 & 610.5 & 610.5 \\
\hline & & 0.46 & 1 & 1.4907 & 1.4264 & 1.4264 \\
\hline \multirow{2}{*}{ M40 } & \multirow{2}{*}{0.42} & 197 & 469 & 625 & 598 & 598 \\
\hline & & 0.42 & 1 & 1.3326 & 1.2750 & 1.2750 \\
\hline
\end{tabular}




\section{Comparing the Mix Proportions and Compressive Strength}

Finalized mix proportions for M20, M25, M30, M35 and M40 grade concrete using packing density and IS code method are presented in Table 3 and 4 respectively.

Using these finalized mix proportions for different grades of concrete final casting was carried out as mentioned in the following section.

In packing density method finalized mix proportions were used for final casting. Six cube specimens were cast ( 3 cube specimens for 7 days curing and 3 cube specimens for 28 days curing). Similarly, in IS method for each grade of concrete six cube specimens were cast ( 3 cube specimens for 7 days curing and 3 cube specimens for 28 days curing). Casting, curing and compressive strength testing procedure was followed according to IS 516-1959 [14].

The average test result of 3 cube specimens is considered for final test result. The results of final casting are presented in Table 5 and Table 6.

Table 5: Compressive strength of cube cast using packing density method

\begin{tabular}{|l|l|l|l|l|}
\hline $\begin{array}{l}\text { Grade of } \\
\text { concrete }\end{array}$ & W/C ratio & Paste content & $\begin{array}{l}\text { Strength of cube (Mpa) (7 } \\
\text { days) }\end{array}$ & $\begin{array}{l}\text { Strength of cube (Mpa) (28 } \\
\text { days) }\end{array}$ \\
\hline M20 & 0.56 & $10 \%$ & 22.8889 & 33.7037 \\
\hline M25 & 0.54 & $15 \%$ & 26.9629 & 38.7407 \\
\hline M30 & 0.5 & $20 \%$ & 30.3333 & 44.4444 \\
\hline M35 & 0.48 & $25 \%$ & 36.6667 & 50.6667 \\
\hline M40 & 0.44 & $30 \%$ & 40.8519 & 54.8048 \\
\hline
\end{tabular}

Table 6: Compressive strength of cube cast using IS code method

\begin{tabular}{|l|l|l|l|}
\hline Grade of concrete & W/C ratio & $\begin{array}{l}\text { Strength of cube (Mpa) }(7 \\
\text { days) }\end{array}$ & $\begin{array}{l}\text { Strength of cube (Mpa) (28 } \\
\text { days) }\end{array}$ \\
\hline M20 & 0.55 & 22.6667 & 31.5555 \\
\hline M25 & 0.52 & 26.2222 & 37.7037 \\
\hline M30 & 0.48 & 31.8518 & 45.6296 \\
\hline M35 & 0.46 & 34.0741 & 48.8889 \\
\hline M40 & 0.42 & 38.2222 & 54.5184 \\
\hline
\end{tabular}

\section{Results and Discussions}

From the Tables 3 and 4, it is clear that fine aggregate particles are required more in case of packing density method compared to IS code method. Therefore, water and cement required in case of packing density method is more. In case of IS method coarse aggregate $20 \mathrm{~mm}$ and $12.5 \mathrm{~mm}$ down sizes are graded based on sieve analysis results but in case of packing density method aggregates quantity are decided based on actual packing of particles. Coarse aggregate particle $20 \mathrm{~mm}$ downsize required will be more in case of packing density method compared to IS method. But both the methods have resulted in nearly same compressive strength at 28 days curing. Coarse aggregate particle may also contribute towards the strength along with bond. In case of packing density, finer aggregate particles required are more and paste required is also more. In this case contribution to the strength due to bond area may be more.

Too many trial calculations were involved for determining paste content and water cement ratio for designing any grade of concrete by packing density method. In addition to this number of trial tests such as flow table test and trial casting for compressive strength test are to be determined in order to arrive at water cement ratio and paste content for a particular grade of concrete. Well established co-relations were not available for packing density method to reduce the time and labour involved in this trial testing and casting. Therefore, here an attempt is made to develop these co-relations between compressive strength (for 7 days and 28 days curing age) and water cement ratio, paste content in excess of void content. 
Data presented in Table 5 are represented in the form of figures. The data from Table 5 are considered to obtain the best fit equation through CURVE EXPERT 1.4. Fig. 7 represents compressive strength (7 days curing) vs water cement ratio for packing density data alone. Similarly Fig. 8 is a plot of compressive strength (7 days curing) vs water cement ratio including IS code and packing density method. Similar plots were obtained for 28 days curing age and they are represented in fig 9 (packing density alone) and fig. 10 (including both IS and packing density method). From fig 7 it is observed that a linear fit with a very good co-relation co-efficient i.e., 0.984 is obtained. Co-efficients a, b, standard error and co-efficient of co-relation for all the figures from 7 to 10 are presented in Table 7 . From the table it is observed that a very good co-relation co-efficient is obtained for packing density alone at the curing age of 7 days and 28 days i.e., 0.984 and 0.988 respectively. Similarly good co-relation co-efficient is obtained for both the data (IS and packing density method) at 7 days and 28 days i.e., 0.953 and 0.961 respectively.

Fig 11 represents compressive strength vs paste content in excess of void content for the data of packing density alone at 7 days curing age and fig 12 represents compressive strength vs paste content in excess of void content for the data of including both IS code and packing density method at 7 days curing age. Similar plots were obtained for 28 days curing age and they are presented in fig 13 (packing density alone) and fig 14 (including both IS and packing density method). From fig 11 to 14 it is observed that a linear fit with very good co-relation co-efficient is obtained. From the Table 7 it is observed that a very good co-relation co-efficient is obtained for packing density alone at the curing age of 7 days and 28 days i.e., 0.995 and 0.998 respectively. Similarly good co-relation co-efficient is obtained for both the data (IS and packing density method) at 7 days and 28 days i.e., 0.988 and 0.994 respectively. However, the co-relations obtained are not generalised as the materials used for study are locally available materials.

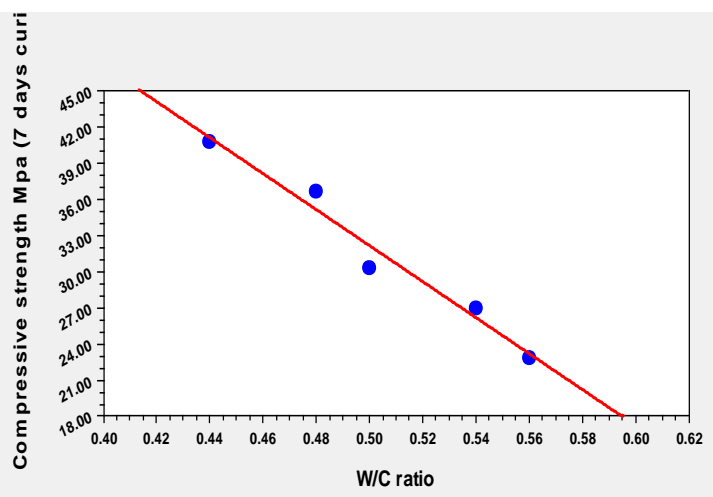

Fig 7: Packing density method at 7 days curing

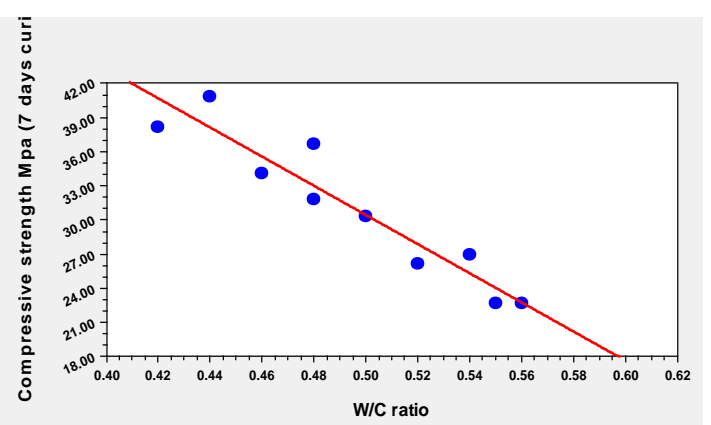

Fig 8: Packing density and IS code method at 7 days curing

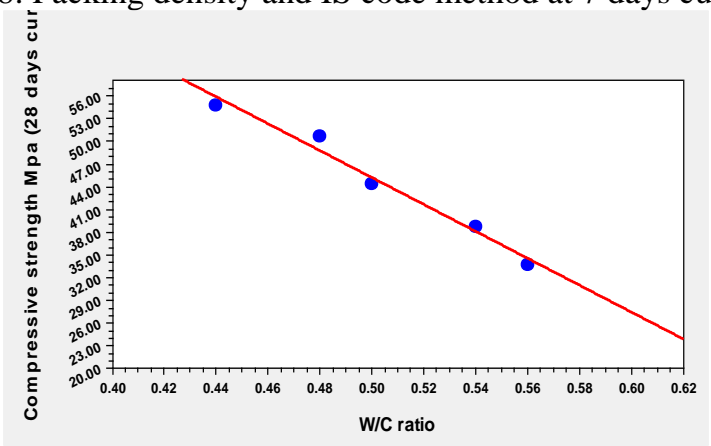

Fig 9: Packing density method at 28 days curing 


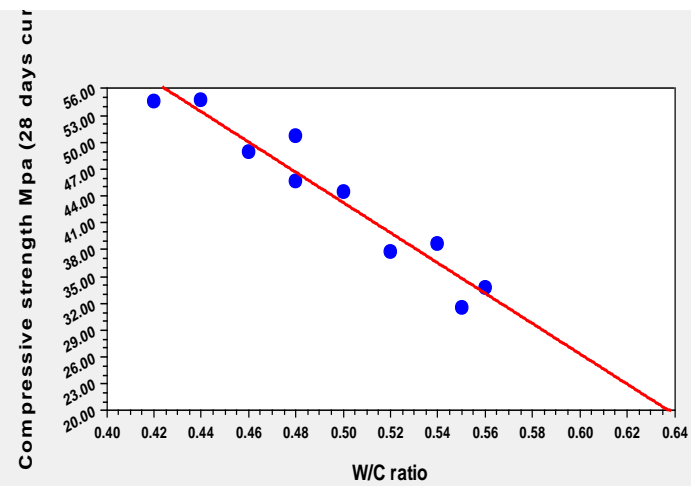

Fig 10: Packing density and IS code method at 28 days curing

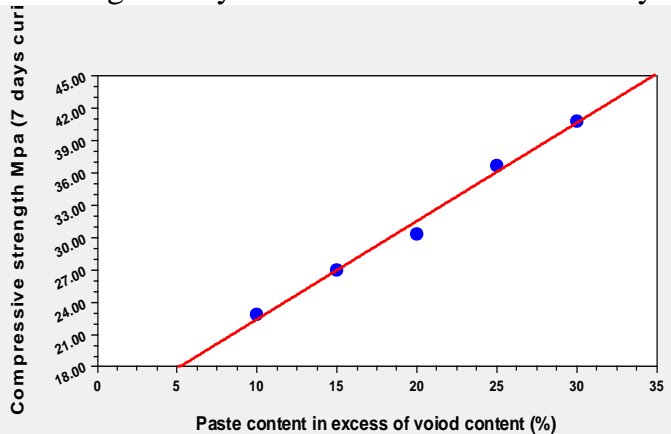

Fig 11: Packing density method at 7 days curing

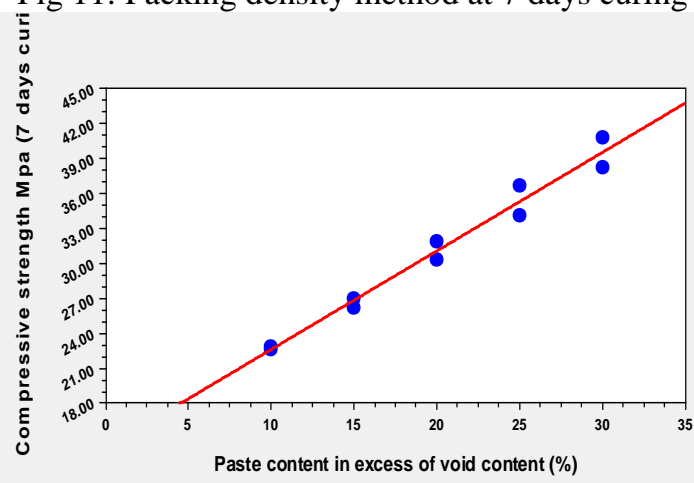

Fig 12: Packing density and IS code method at 7 days curing

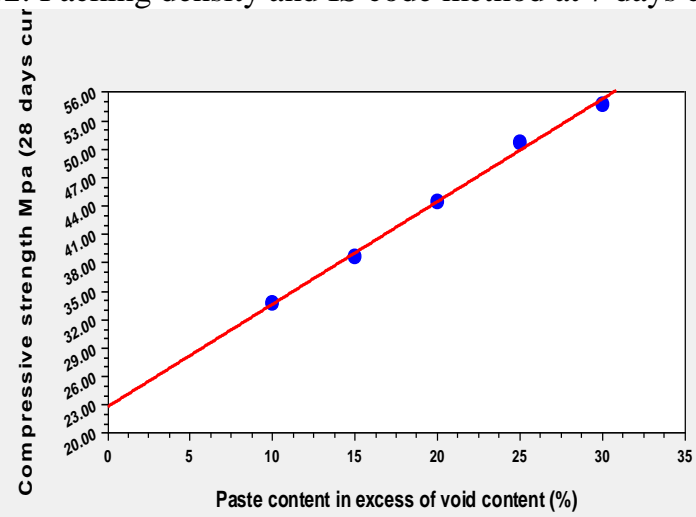

Fig 13: Packing density method at 28 days curing 


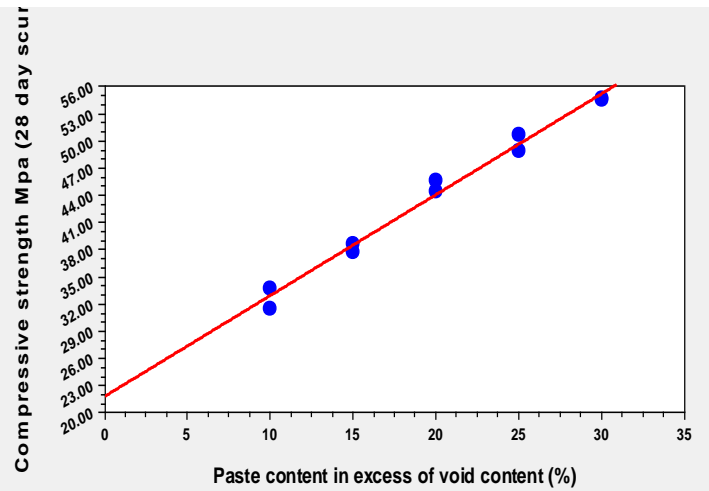

Fig 14: Packing density and IS code method at 28 days curing

Table 7: Equation co-efficients and co-relation co-efficients

\begin{tabular}{|c|c|c|c|c|c|c|}
\hline \multicolumn{7}{|c|}{ Linear fit: $y=a+b x$} \\
\hline \multirow{2}{*}{$\begin{array}{l}\text { Figure } \\
\text { no. }\end{array}$} & \multirow{2}{*}{ Mix design method } & \multirow{2}{*}{$\begin{array}{l}\text { Curing } \\
\text { age }\end{array}$} & \multicolumn{2}{|c|}{ Co-efficients } & \multirow{2}{*}{$\begin{array}{l}\text { Standard error } \\
\text { (s) }\end{array}$} & \multirow{2}{*}{$\begin{array}{l}\text { Co-relation } \\
\text { co-efficient(r) }\end{array}$} \\
\hline & & & A & $\mathrm{b}$ & & \\
\hline \multicolumn{7}{|c|}{ Compressive strength (Mpa) vs Water cement ratio } \\
\hline 6.1 & Packing density & 7 & $1.069 \mathrm{E}+02$ & $-1.495 \mathrm{E}+02$ & 1.462 & 0.985 \\
\hline 6.2 & Packing density and IS code & 7 & $9.439 \mathrm{E}+01$ & $-1.279 \mathrm{E}+02$ & 2.174 & 0.953 \\
\hline 6.3 & Packing density & 28 & $1.340 \mathrm{E}+02$ & $-1.775 \mathrm{E}+02$ & 1.468 & 0.989 \\
\hline 6.4 & Packing density and IS code & 28 & $1.278 \mathrm{E}+02$ & $-1.691 \mathrm{E}+02$ & 2.441 & 0.961 \\
\hline \multicolumn{7}{|c|}{ Compressive strength (Mpa) vs Paste content in excess of void content (\%) } \\
\hline 6.5 & Packing density & 7 & $1.329 \mathrm{E}+01$ & $9.126 \mathrm{E}-01$ & 0.823 & 0.995 \\
\hline 6.6 & Packing density and IS code & 7 & $1.416 \mathrm{E}+01$ & $8.459 \mathrm{E}-01$ & 1.028 & 0.988 \\
\hline 6.7 & Packing density & 28 & $2.282 \mathrm{E}+01$ & $1.083 \mathrm{E}+00$ & 0.566 & 0.998 \\
\hline 6.8 & Packing density and IS code & 28 & $2.182 \mathrm{E}+01$ & $1.112 \mathrm{E}+00$ & 1.001 & 0.994 \\
\hline
\end{tabular}

\section{Conclusions}

1. The packing density value will remain same irrespective of grade of concrete.

2. In packing density method, paste content in excess of void content will increase with the increase in grade of concrete.

3. In case of packing density method water cement ratio decreases with increase in grade of concrete.

4. In packing density too many trial calculations, trial tests and trial casting are to be done in order to arrive at water cement ratio and paste content for a particular grade of concrete. These co-relation curves helps to reduce the trials involved in determining the water cement ratio and paste content for the given grade of concrete.

5. The water and cement content for packing density and IS code method is nearly same for any particular grade of concrete.

6. The workability of concrete achieved is more in packing density method compared to IS code method for the same grade of concrete, as the water cement ratio is slightly higher in packing density method than IS code method.

7. The fine aggregate particles required are more in case of packing density method compared to IS code method. Therefore, water and cement required in case of packing density is more.

8. The fine aggregate and coarse aggregate $20 \mathrm{~mm}$ down size required is more in packing density method and coarse aggregate $12.5 \mathrm{~mm}$ down size required is more in IS method. But the cube compressive strength results at 7 days and 28 days curing age obtained by both the methods are nearly same.

9. Though the material quantities are different in both the methods, compressive strength achieved at 28 days by packing density and IS code methods are nearly same. 
10. A very good correlation coefficient is obtained for the Co-relation curves with a minimum of 0.953 to maximum of 0.998 .

11. Co-relation curves can be used to decide the water cement ratio and paste content in excess of void content for the given grade of concrete.

\section{References}

[1] Wong, H. C. H. and Kwan, K. H. A., "Packing density: A key concept for mix design of high performance concrete".

[2] Wong, H. C. H. and Kwan, K. H. A. (2008) "Packing density of cementitious materials: part 2 - packing flow of OPC + PFA + CSF". Materials and structures, 41:773 - 784

[3] Fennis, S. A. A. M. and Walraven, J. C. (2008) "Measuring the packing density to lower the cement content in concrete".

[4] Wong, H. C. H. and Kwan, K. H. A. (2008) "Packing density of cementitious materials: part 1 - measurement using a wet packing method". Materials and structures, 41:689-701.

[5] Glavind, M. and Peterson, E. J. (1999) "Packing calculations applied for concrete mix design". University of Dundee.

[6] Kantha Rao, V. V. L. And Krishnamoorthy, S., "Aggregate mixtures for least-void content for use in polymer concrete".

[7] Powers, T. C. (1968) The properties of fresh concrete. John Wiley and Sons, Inc.. New York.

[8] Indian standard code of practice for, "Specification for 53 grade ordinary Portland cement", IS 12269 - 1987, Bureau of Indian Standards, New Delhi.

[9] Indian standard code of practice for, "Specification for coarse and fine aggregates from natural sources for concrete", IS 383 1970, Bureau of Indian Standards, New Delhi.

[10] Indian standard code of practice for, "Concrete admixtures - specification”, IS 9103 - 1999, Bureau of Indian Standards, New Delhi.

[11] Indian standard code of practice for, "Methods of test for aggregates for concrete", IS 2386 (Part III) - 1963, Bureau of Indian Standards, New Delhi.

[12] Indian standard code of practice for, "Methods of sampling and analysis of concrete", IS 1199 - 1959, Bureau of Indian Standards, New Delhi.

[13] Indian standard code of practice for, "Concrete mix proportioning - Guidelines" IS 10262 - 2009, Bureau of Indian Standards, New Delhi.

[14] Indian standard code of practice for, "Methods of tests for strength of concrete", IS 516 - 1959, Bureau of Indian Standards, New Delhi. 